\title{
ANTIOXIDANT ACTIVITY OF COWPEA PROTEIN ISOLATE HYDROLYZED BY PEPSIN
}

\author{
M. Mune Mune ${ }^{a *}$, D. Saxena ${ }^{\mathrm{b}}$ and S. MinKA ${ }^{\mathrm{c}}$ \\ ${ }^{\mathrm{a}}$ The Higher Institute of Sahel, The University of Maroua, P.O. Box 46, Maroua. Cameroon \\ ${ }^{\mathrm{b}}$ Sant Longowal Institute of Engineering and Technology (SLIET), Longowal. India \\ ${ }^{\mathrm{c}}$ Department of Biochemistry, University of Yaounde I, PO Box 812, Yaounde. Cameroon
}

(Received: 27 July 2013; accepted: 17 November 2013)

\begin{abstract}
Antioxidant activity was studied for hydrolysates obtained from cowpea protein isolate by enzymatic hydrolysis using pepsin. Effects of 3 hydrolysis parameters: $\mathrm{pH}$, temperature, and time were analysed using response surface methodology. A second-order polynomial model was used for predicting antioxidant activity of the hydrolysates. This model was adequate to fit experimental data and explained more than $85 \%$ of the variation. Interaction between $\mathrm{pH}$ and temperature was the major effect affecting antioxidant activity. Optimum antioxidant activity was observed after hydrolysis for $176 \mathrm{~min}$, at $\mathrm{pH} 2.15$, and temperature $38.2^{\circ} \mathrm{C}$. Under these conditions, the predicted antioxidant activity $(22.69 \%)$ was in agreement with the experimental one. Degree of hydrolysis of the hydrolysate under optimum conditions was $25.70 \%$, and the electrophoretic profile revealed the cleavage of several protein bands present in the isolate.
\end{abstract}

Keywords: cowpea, hydrolysate, pepsin, optimization, antioxidant activity

There is a continuous search of better and more effective antioxidants for use in food and non-food industries. These substances play a major role in the prevention of lipid oxidation, which causes the formation of free radicals. The free radicals produced are involved in the deterioration of food products, and also associated to many pathological conditions. The use of artificial antioxidants is restricted or prohibited in some countries, because of their toxicity (Iто et al., 1986). Attention is then focused on natural antioxidants, and recently on plant protein hydrolysates (CumBY et al., 2008).

Principally all proteins may be considered as the precursors of antioxidant peptides (DziubA et al., 2004), which are inactive in the protein sequence and may reveal biological activity after being released by proteolytic enzymes. However, to produce hydrolysates with desirable properties, it is necessary to undertake studies to find the right proteolytic enzyme for a protein substrate, as well as to select factors with major effects on the proteolysis. Tropical legumes can be considered as a source of cheap, accessible, and safe proteins for a large-scale production of antioxidative peptides. In this regards, cowpea (Vigna unguiculata L. Walp) is widely produced in the world, with a total annual global production over 3 million tons (CGIAR, 1997). This legume is a good source of protein (18-35\%) rich in histidine, leucine, and aromatic amino acids (Mwasaru et al., 1999). Peptides containing these amino acids have been shown to possess strong antioxidant activity (Pinlanto, 2006).

Depending on the enzyme used, hydrolysis of proteins depends on the combination of factors such as time, temperature, $\mathrm{pH}$, ionic strength, and enzyme to substrate ratio. Then, it is necessary to strictly regulate the process, to include the possibility of determining when to

\footnotetext{
* To whom correspondence should be addressed.

Phone: (+237) 99309667; e-mail: alainmune@yahoo.fr
} 
stop if the wanted peptides are produced, in order not to lose them. In this regards, response surface methodology (RSM) is a useful technique that has been successfully applied for the optimization of the enzymatic hydrolysis process using different substrates and proteases, with the finality of producing antioxidant peptides. The aim of this study was to study the effects of $\mathrm{pH}$, temperature, and time on DPPH scavenging activity of cowpea protein hydrolysates produced by pepsin, and to find the optimal conditions for hydrolysis.

\section{Materials and methods}

\subsection{Preparation of cowpea flour}

Cowpea flour was prepared as described by MunE MunE and co-workers (2008), then defatted by the Soxhlet apparatus for $12 \mathrm{~h}$ and stored at about $4{ }^{\circ} \mathrm{C}$. The flour contained $4.44 \%$ moisture and $24.99 \%$ protein, determined according to A.O.A.C. (1990) methods.

\subsection{Preparation of cowpea protein concentrate}

Cowpea protein concentrate was prepared as described by MunE MunE and co-workers (2008) with some modifications. An aliquot (10 g) of defatted cowpea flour was mixed with $100 \mathrm{ml}$ of $\mathrm{NaCl}$ solution $(0.15 \mathrm{M})$, the $\mathrm{pH}$ was adjusted to 9.9 and the mixture was stirred for 120 minutes at room temperature $\left(\max 30^{\circ} \mathrm{C}\right)$. The resultant slurry was then centrifuged at 5000 r.p.m. for 20 min using an Eltek centrifuge (Mumbai, India). The $\mathrm{pH}$ of the resultant supernatant was adjusted to 4.5 under stirring, the precipitated proteins were washed once in distilled water and recovered by centrifugation at 5000 r.p.m. for $20 \mathrm{~min}$. The protein was resuspended in water at about 1:1 (w/v), the $\mathrm{pH}$ was adjusted to 7.0 , then freeze-dried, ground, and passed through a $150 \mu \mathrm{m}$ mesh sieve. The concentrate contained $86.87 \%$ protein determined by the Kjeldahl method (A.O.A.C., 1990).

\subsection{Experimental design}

A central composite rotatable design (CCRD) with three variables was used to study the response pattern and to determine the optimum combination of the variables. The variables optimized were $\mathrm{pH}(1.50-2.50)$, temperature $\left(32-42{ }^{\circ} \mathrm{C}\right)$, and time $(30-240 \mathrm{~min})$, each at 5 coded levels $-1.682,-1,0,1$ and 1.682 as shown in Table 1 . The CCRD shown in Table 2 was arranged to allow fitting an appropriate regression model using a multiple regression program. Four replicates (treatments 15-18) at the centre of the design were used to allow the estimation of the pure error sum of squares. Experiments were randomized in order to minimise the effects of unexplained variability in the observed responses due to extraneous factors.

Table 1. Experimental values and coded levels of the independent variables for CCRD

\begin{tabular}{lccccccc}
\hline Variable & \multicolumn{2}{c}{ Symbols } & \multicolumn{5}{c}{ Levels } \\
\hline & Coded & Uncoded & -1.682 & -1 & 0 & 1 & 1.682 \\
$\mathrm{pH}$ & $\mathrm{X}_{1}$ & $\mathrm{x}_{1}$ & 1.50 & 1.70 & 2.00 & 2.30 & 2.50 \\
Temperature $\left({ }^{\circ} \mathrm{C}\right)$ & $\mathrm{X}_{2}$ & $\mathrm{x}_{2}$ & 32 & 34 & 37 & 40 & 42 \\
Time (min) & $\mathrm{X}_{3}$ & $\mathrm{x}_{3}$ & 30 & 73 & 135 & 197 & 240 \\
\hline
\end{tabular}


Table 2. CCRD Design arrangement and responses in terms of DPPH scavenging activity

\begin{tabular}{lcccc}
\hline Exp. & $\mathrm{pH}$ & Temp. & $\begin{array}{c}\text { Time } \\
(\mathrm{min})\end{array}$ & $\begin{array}{c}\text { DPPH } \\
(\%)\end{array}$ \\
& $\left(\mathrm{X}_{1}\right)$ & $\left(\mathrm{X}_{2}\right)$ & $\left(\mathrm{X}_{3}\right)$ & $\left(\mathrm{Y}_{1}\right)$ \\
\hline 1 & -1 & -1 & -1 & 13.24 \\
2 & 1 & -1 & -1 & 0.15 \\
3 & -1 & 1 & -1 & 11.18 \\
4 & 1 & 1 & -1 & 13.25 \\
5 & -1 & -1 & 1 & 22.15 \\
6 & 1 & -1 & 1 & 8.90 \\
7 & -1 & 1 & 1 & 0.65 \\
8 & 1 & 1 & 1 & 20.85 \\
9 & -1.682 & 0 & 0 & 20.85 \\
10 & 1.682 & 0 & 0 & 10.42 \\
11 & 0 & -1.682 & 0 & 6.84 \\
12 & 0 & 1.682 & 0 & 5.32 \\
13 & 0 & 0 & -1.682 & 11.07 \\
14 & 0 & 0 & 1.682 & 16.94 \\
15 & 0 & 0 & 0 & 23.34 \\
16 & 0 & 0 & 0 & 20.74 \\
17 & 0 & 0 & 0 & 22.04 \\
18 & 0 & 0 & 0 & 23.50 \\
\hline & & & & \\
\hline
\end{tabular}

*coding is done as follows: $\mathrm{X}_{1}=\left(\mathrm{x}_{1}-2\right) / 0.3 ; \mathrm{X}_{2}=\left(\mathrm{x}_{2}-37\right) / 3 ; \mathrm{X}_{3}=\left(\mathrm{x}_{3}-135\right) / 62$

The variables were coded according to the following equation:

$$
\mathrm{X}_{\mathrm{i}}=\left(\mathrm{x}_{\mathrm{i}}-\overline{\mathrm{x}}_{\mathrm{i}}\right) / \Delta \mathrm{x}_{\mathrm{i}}
$$

where $\mathrm{X}_{\mathrm{i}}$ is the coded value of an independent variable, $\mathrm{x}_{\mathrm{i}}$ is the real value of an independent variable, $\bar{x}_{i}$ is the real value of an independent variable at the centre point, $\Delta x_{i}$ is the step change.

\subsection{Enzymatic hydrolysis with pepsin}

The proteolysis was performed based on the method described by MunE MunE and coworkers (2011). Cowpea protein concentrate was homogenised in distilled water, the $\mathrm{pH}$ was adjusted to $1.50-2.50$ using $2 \mathrm{M} \mathrm{HCl}$, and the mixture was stirred for $2 \mathrm{~h}$ at room temperature $\left(25 \pm 2{ }^{\circ} \mathrm{C}\right)$. The mixture was preincubated at $32-42{ }^{\circ} \mathrm{C}$ for $30 \mathrm{~min}$, then a pepsin $(1: 3000$, Himedia) solution of $2.3 \mathrm{mg} \mathrm{ml}^{-1}$ in water was added to obtain a final enzyme/substrate ratio $(\mathrm{E} / \mathrm{S})$ of $2 \%(\mathrm{w} / \mathrm{w})$, and a solid/liquid ratio of $1 / 20(\mathrm{w} / \mathrm{v})$. The E/S was chosen low for an economical reason and potential industrial application. The reaction was allowed to proceed under constant stirring at $37^{\circ} \mathrm{C}$ for 30 to $240 \mathrm{~min}$, and the $\mathrm{pH}$ was maintained at $1.5-2.50$ by the addition of $1 \mathrm{M} \mathrm{NaOH}$. At appropriate reaction time, the $\mathrm{pH}$ of the mixtures was adjusted to 7 with $2.5 \mathrm{M} \mathrm{NaOH}$. The reaction was stopped by heating at $100{ }^{\circ} \mathrm{C}$ for $10 \mathrm{~min}$, than 
cooled in an ice bath at $4{ }^{\circ} \mathrm{C}$. The mixtures were then centrifuged at 5000 r.p.m. for 15 min, the supernatants freeze-dried and stored at $4{ }^{\circ} \mathrm{C}$.

\subsection{Degree of hydrolysis}

The DH was defined as the percent ratio of the number of peptide bonds broken to the total number of peptide bonds in the substrate studied and the calculation formula was: $\mathrm{DH}(\%)=$ alpha-amino nitrogen contenttotal nitrogen content $\times 100 \%$. The alpha-amino nitrogen was determined by a formol titration method (CHEN et al., 2003) and the total nitrogen content was determined by A.O.A.C. (1990) method.

\subsection{1,1-diphenyl-2-picrylhydrazyl (DPPH) scavenging activity}

The scavenging effects of cowpea protein hydrolysates $(\mathrm{CPH})$ on the DPPH free radical were measured basically as described by SHIMADA and co-workers (1992). Briefly, a $1.5 \mathrm{ml}$ aliquot

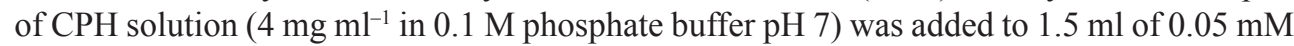
DPPH in $95 \%$ ethanol. The mixture was vortexed for $10 \mathrm{~s}$ and left for $30 \mathrm{~min}$ at room temperature. The absorbance of the resulting solution was measured at $517 \mathrm{~nm}$ using the Hach DR 5000 spectrophotometer. The scavenging effect was expressed as:

DPPH radical scavenging activity $(\%)=$

(blank absorbance-sample absorbance) $\times 100 /$ blank absorbance

where the DPPH blank is the value of $1.5 \mathrm{ml}$ of $0.1 \mathrm{M}$ phosphate buffer $\mathrm{pH} 7$ mixed with 1.5 $\mathrm{ml}$ of ethanol containing $0.05 \mathrm{mM} \mathrm{DPPH}$. All experiments were carried out in triplicate.

\subsection{Polyacrylamide gel electrophoresis}

SDS-PAGE is performed by the method of LAEMMLI (1970). The gel system consisted of a $10 \%$ polyacrylamide-resolving gel $(\mathrm{pH} 8.8)$ and a 5\% stacking gel ( $\mathrm{pH}$ 6.8). The lengths of the resolving and stacking gels are 12 and $3 \mathrm{~cm}$, respectively, with a gel thickness of $1.5 \mathrm{~mm}$. Molecular weight markers $(30-150 \mathrm{kDa})$ were purchased from Gencript Corp (NJ, USA).

\subsection{Statistical analysis}

A second-order polynomial equation was used to fit experimental data given in Table 2. The model proposed for the response is given as follows:

$$
\mathrm{Y}_{\mathrm{i}}=\mathrm{a}_{0}+\mathrm{a}_{1} \mathrm{X}_{1}+\mathrm{a}_{2} \mathrm{X}_{2}+\mathrm{a}_{3} \mathrm{X}_{3}+\mathrm{a}_{11} \mathrm{X}_{1}{ }^{2}+\mathrm{a}_{22} \mathrm{X}_{2}^{2}+\mathrm{a}_{33} \mathrm{X}_{3}{ }^{2}+\mathrm{a}_{12} \mathrm{X}_{1} \mathrm{X}_{2}+\mathrm{a}_{13} \mathrm{X}_{1} \mathrm{X}_{3}+\mathrm{a}_{23} \mathrm{X}_{2} \mathrm{X}_{3}
$$

where $\mathrm{Y}_{\mathrm{i}(1-2)}$ is predicted response for $\mathrm{DH}$ and solubility of cowpea protein hydrolysates. The $a_{0}$ value is that of the fitted response at the centre point of the design, $a_{1}, a_{2}$, and $a_{3}$ are linear terms, $\mathrm{a}_{12}, \mathrm{a}_{13}$, and $\mathrm{a}_{23}$ are interaction effects, $\mathrm{a}_{11}, \mathrm{a}_{22}$, and $\mathrm{a}_{33}$ are squared effects. Optimization of the fitted polynomial was carried out by the partial derivative method. The optimum condition was verified by conducting experiments under that condition. Experimental and predicted responses were compared. The fitted polynomial equation was expressed as surface and contour plots. The computer software used for this study was STATISTICA (version 5.5, 2002; Statsoft Inc., USA). 


\section{Results and discussion}

\subsection{Fitting the models}

Antioxidant activity (AA) was measured as DPPH scavenging activity and used as the response during hydrolysis of cowpea protein isolate by pepsin under different $\mathrm{pH}$, temperature, and time conditions. Multiple regression equations were generated relating the predicted response to coded levels of variables. The regression coefficients were determined by the least square method, the following model explained the experimental data:

$$
\begin{gathered}
\mathrm{Y}=22.401 .58 \mathrm{X}_{1}-2.39 \mathrm{X}_{1}^{2}-0.08 \mathrm{X}_{2}-5.77 \mathrm{X}_{2}^{2}+1.80 \mathrm{X}_{3}-2.96 \mathrm{X}_{3}^{2}+ \\
+6.07 \mathrm{X}_{1} \mathrm{X}_{2}+2.25 \mathrm{X}_{1} \mathrm{X}_{3}-2.57 \mathrm{X}_{2} \mathrm{X}_{3}
\end{gathered}
$$

where $\mathrm{Y}$ is the predicted DPPH scavenging activity, $\mathrm{X}_{1}, \mathrm{X}_{2}$, and $\mathrm{X}_{3}$ are the coded values of $\mathrm{pH}$, temperature, and time.

Analysis of variable was calculated to test model adequacy. The data obtained using ANOVA appropriate to the experimental design are presented in Table 3 . The probability of the model was significant at $\mathrm{P}<0.000$. The high value of coefficient of determination $\left(\mathrm{R}^{2} \mathrm{adj}=0.852\right)$ demonstrated that the model explained $85.2 \%$ of the variation in the response. In addition, plot of experimental versus predicted value indicated a good fit $(\mathrm{R} \geq 0.96$; $\mathrm{P}<0.000)$. On the other hand, the lack of fit was found to be insignificant $(\mathrm{P}>0.05)$. The lack of fit measures the failure of the model to represent data in the experimental domain, at points which are not included in the regression (Myers \& MONTGOMERY, 2002). It can be concluded from these results that the model satisfactorily describes the process.

Table 3. ANOVA for the quadratic model

\begin{tabular}{lrrrrc}
\hline Source & Df & \multicolumn{1}{c}{ SS } & \multicolumn{1}{c}{ MS } & $F$-value & P-value \\
\hline Model & 1 & 2013.71 & 2013.71 & 228.85 & 0.000 \\
X1 & 1 & 34.19 & 34.19 & 3.89 & 0.084 \\
$X_{11}$ & 1 & 72.16 & 72.16 & 8.20 & 0.021 \\
$\mathrm{X}_{2}$ & 1 & 0.08 & 0.08 & 0.01 & 0.925 \\
$\mathrm{X}_{22}$ & 1 & 420.60 & 420.60 & 47.80 & 0.000 \\
$\mathrm{X}_{3}$ & 1 & 44.28 & 44.28 & 5.03 & 0.055 \\
$\mathrm{X}_{33}$ & 1 & 111.15 & 111.15 & 12.63 & 0.007 \\
$\mathrm{X}_{12}$ & 1 & 295.18 & 295.18 & 33.55 & 0.000 \\
$\mathrm{X}_{13}$ & 1 & 40.39 & 40.39 & 4.59 & 0.065 \\
$\mathrm{X}_{23}$ & 1 & 53.02 & 53.02 & 6.03 & 0.040 \\
Residual & 8 & 70.39 & 8.80 & & \\
Lack of fit & 5 & 65.40 & 13.08 & 7.86 & 0.06 \\
Pure error & 3 & 4.99 & 1.66 & & \\
Total & 17 & 1009.41 & & & \\
\hline
\end{tabular}

$\mathrm{R}^{2}=0.851806$; SS: sum of square; Df: degree of freedom; MS: mean square 


\subsection{Response surface plotting}

The response surfaces and contour plots obtained from eq. 3, presenting the effects of 2 variables on $\mathrm{AA}$ of $\mathrm{CPH}$ where the third one was constant at the central level, are presented in Fig. 1A-C.
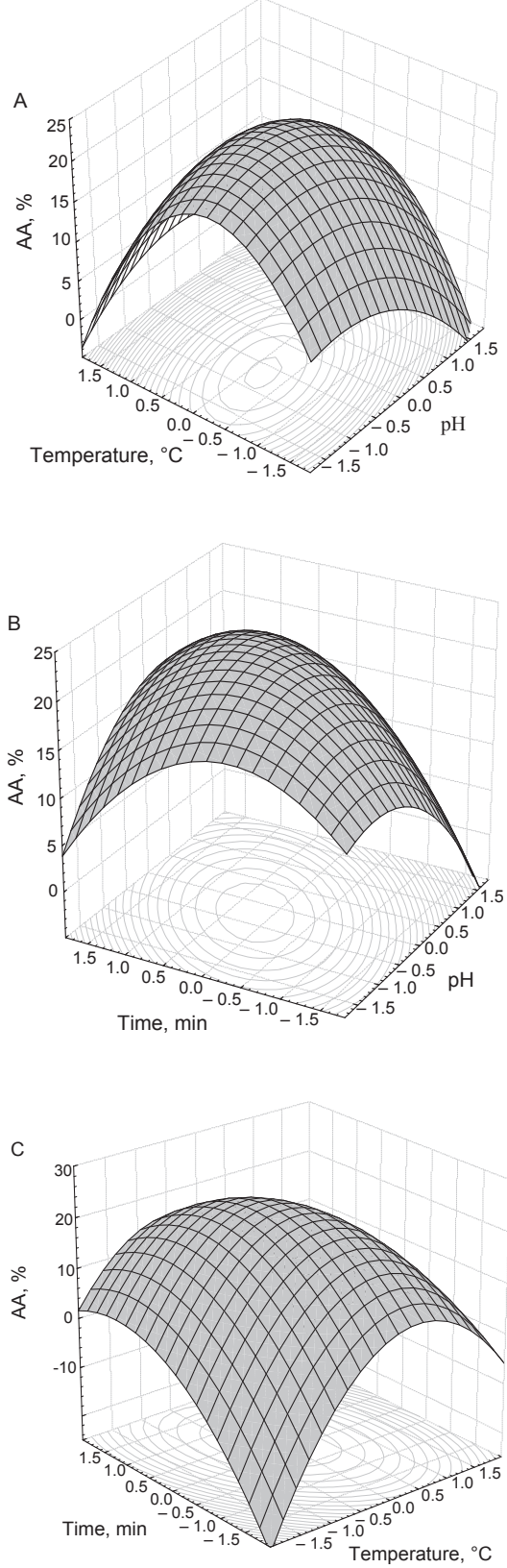

Fig. 1. Response surface and contour plot of the effects of factors on antioxidant activity (AA); A: $\mathrm{pH}$ and temperature; $\mathrm{B}$ : $\mathrm{pH}$ and time; $\mathrm{C}$ : temperature and time 
2.2.1. Effect of $\mathrm{pH}$ and temperature on $A A$. The $\mathrm{AA}$ of $\mathrm{CPH}$ is a quadratic function of $\mathrm{pH}$ and temperature. The two effects are negative and significant at $\mathrm{P}<0.05$ (Table 3). The AA increased with increasing $\mathrm{pH}$ and temperature till the maximum, and then decreased thereafter (Fig. 1A). The maximum value of AA was observed around $\mathrm{pH}$ and temperature coded of -1.0 to -0.3 (1.70 to 1.91 uncoded) and -0.5 to 0.0 (35.5 to $37^{\circ} \mathrm{C}$ uncoded), respectively. Interaction between $\mathrm{pH}$ and temperature was positive and significant at $\mathrm{P}<0.00$. The variation of $\mathrm{pH}$ and temperature probably affected the protein structure, leading to exposure to the enzyme of more cleavage sites and exposing the hydrophobic or proton donating residues buried inside the molecule, then contributed to the AA of the hydrolysates (CHEISON et al., 2011).

2.2.2. Effect of $p H$ and time on $A A$. A curvilinear variation in $\mathrm{AA}$ of $\mathrm{CPH}$ was observed with increasing $\mathrm{pH}$ and time (Fig. 1B). The quadratic effect of time was negative and significant at $\mathrm{P}<0.05$ (Table 3). The maximum AA was observed at coded $\mathrm{pH}$ and time around -0.5 to 0.0 (1.85 to 2.0 uncoded) and 0.0 to 0.5 (135 to 166 min uncoded), respectively. And, generally high AA of $\mathrm{CPH}$ was observed at combined low or high values of $\mathrm{pH}$ and time. Combination of long time and high $\mathrm{pH}$, probably affected AA of $\mathrm{CPH}$ by increasing extent of hydrolysis of proteins, and liberation of high antioxidant peptides (Sun et al., 2011).

2.2.3. Effect of temperature and time on $A A$. The shape of the response surface indicated that there was significant interaction between temperature and time on AA of CPH (Fig. 1C). The interaction was negative and significant at $\mathrm{P}<0.05$. The AA increased with increasing temperature and time up to the maximum, and then decreased thereafter. The maximum was observed at coded temperature and time around -0.3 to 0.3 (36.1 to $37.9^{\circ} \mathrm{C}$ uncoded) and 0.2 to 0.7 (147 to 178 min uncoded), respectively. It could be observed that high or low temperature was not favourable for the production of antioxidant peptides from cowpea protein isolate hydrolyzed by pepsin.

\subsection{Optimization}

The predicted optimum conditions were found by the partial derivative method. The first derivatives of the eq. 3 were done as follows:

$$
\begin{gathered}
-4.78 \mathrm{X}_{1}+6.07 \mathrm{X}_{2}+2.25 \mathrm{X}_{3}-1.58=0 \\
-11.54 \mathrm{X}_{2}+6.07 \mathrm{X}_{1}+2.57 \mathrm{X}_{3}-0.08=0 \\
-5.92 \mathrm{X}_{3}+2.25 \mathrm{X}_{1}+2.57 \mathrm{X}_{2}+1.80=0
\end{gathered}
$$

The system of linear eq. 4 was solved and the predicted optimum AA corresponding to $22.61 \%$ was reached at $\mathrm{pH}$ coded of 0.49 (2.15 uncoded), temperature coded of $0.40\left(38.2^{\circ} \mathrm{C}\right.$ uncoded) and time coded of 0.67 (176 min uncoded).

The validity of the mathematical model was confirmed by conducting additional experiments under the predicted optimum conditions. The mean of tri replicates determination was $22.69( \pm 0.92) \%$, and non significant $(\mathrm{P}>0.05)$ difference was found between predicted and experimental values of AA activity of $\mathrm{CPH}$. At these optimum conditions, degree of hydrolysis of hydrolysate was $25.70 \%$. 


\subsection{Electrophoretic profile}

The SDS-PAGE profiles of cowpea protein isolate and the hydrolysate obtained under optimum conditions are shown in Fig. 2. Two major bands of about 65 and $30 \mathrm{kDa}$ were observed on the SDS-PAGE profile of the isolate. These bands probably corresponded to subunits of 7S globulin (vignin) as noted by FreITAS and co-workers (2004). Production of antioxidant peptides is associated with the hydrolysis of vignin, as observed by loss of intensity of bands and appearance of a new band of about $42 \mathrm{kDa}$. Therefore, small and medium size peptides had a significant effect on AA of cowpea protein hydrolysate.

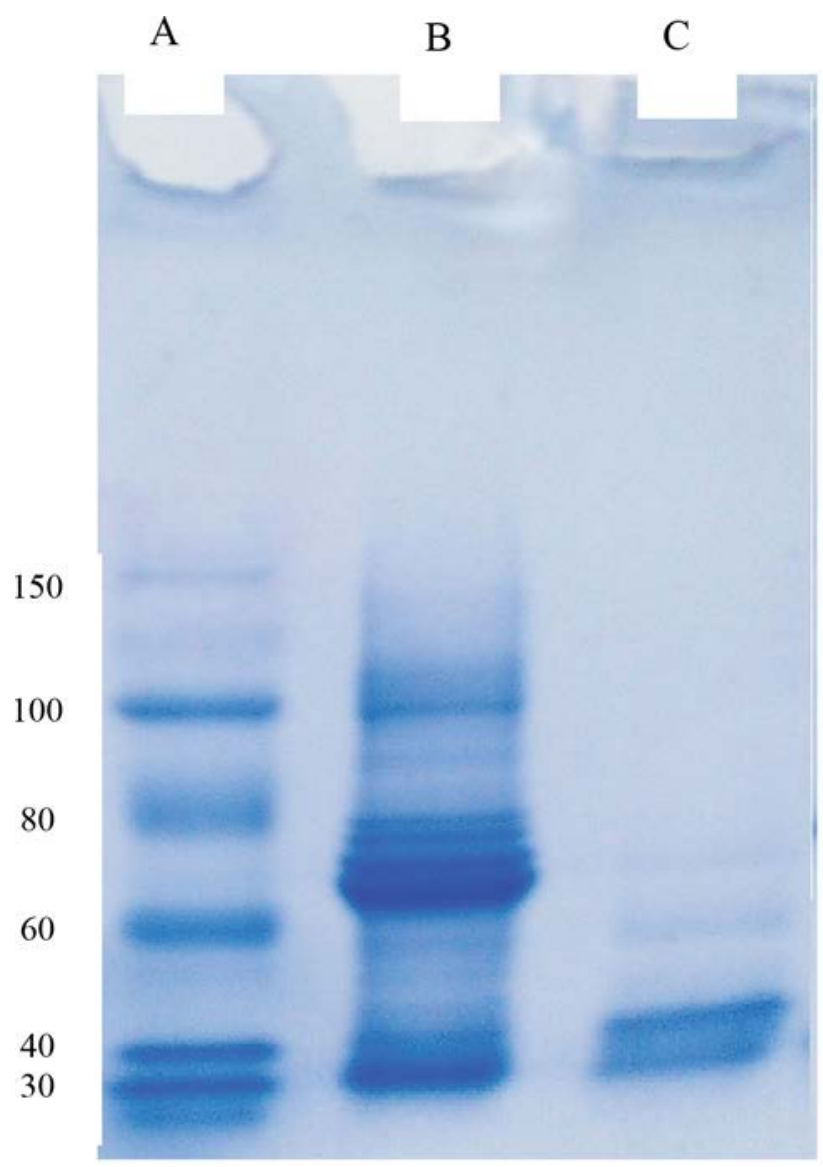

Fig. 2. SDS-PAGE profile of cowpea protein isolate (column B) and hydrolysate (column C). Column A consists of molecular weight markers

\section{Conclusions}

This study showed that cowpea protein isolate exhibited noticeable antioxidant activity following hydrolysis with pepsin. Adequate combination of hydrolysis parameters, $\mathrm{pH}$, temperature, and time, was important for the production of cowpea protein hydrolysates with 
high $\mathrm{AA}$, and interaction between $\mathrm{pH}$ and temperature was significant. Optimum conditions were found by response surface methodology, and under these conditions DPPH scavenging activity of CPH was $22.69 \%$. SDS-PAGE analysis revealed the cleavage of several protein bands present in the isolate after hydrolysis. So, cowpea protein hydrolysates could be useful ingredients of functional foods.

This work was done under the research training fellowship for developing country scientists (RTFDCS) received by Dr. M. Mune Mune (July-December 2012) at Sant Longowal Institute of Engineering and Technology.

\section{References}

A.O.A.C. (1990): Official methods of analysis (15 ${ }^{\text {th }}$ ed.). Association of Official Analytical Chemists, Arlington, USA, Method 970.87.

Cheison, S.C., Lai, M.-Y., Leeb, E. \& KuloziK, U. (2011): Hydrolysis of $\beta$ lactoglobulin by trypsin under acidic pH and analysis of the hydrolysates with MALDI-TOF-MS/MS. Fd Chem., 125, 1241-1248.

CGIAR (1997): Cowpea (Vigna unguiculata). -in: Priorities and strategies for resource allocation during 19982000. The Consultative Group on International Agricultural Research. CGIAR Technical advisory report 1997, WHO, Geneva.

Chen, J.H., Tao, L. \& Li, J. (2003): The formol titration method. Experiments of biochemistry. Science Press, Beijing, pp. 57-58.

Cumby, N., Zhong, Y., Naczk, M. \& Shahidi, F. (2008): Antioxidant activity and water-holding capacity of canola protein hydrolysates. Fd Chem., 109, 144-148.

Dziuba, J., Niklewicz, M., Iwaniak, A., Darewicz, M. \& Minkiewicz, P. (2004): Bioinformatic-aided prediction for release possibilities of bioactive peptides from plant proteins. Acta Alimentaria, 33, 227-235.

Freitas, L.R., Teixeira, A.R. \& Ferreira, R.B. (2004): Characterization of the proteins from Vigna unguiculata seeds. J. Agric. Fd Chem., 52, 1682-1687.

Ito, N., Hirose, M., Fukushima, S., Tsuda, H., Shirai, T. \& Tatematsu, M. (1986): Studies on antioxidants: Their carcinogenic and modifying effects on chemical carcinogenesis. Fd Chem. Toxicol., 24, 1099-1102.

LAEMmLI, U.K. (1970): Cleavage of structural proteins during the assembly of the head of bacteriophage T4. Nature, $227,680-685$.

Mune Mune, M.A., MinkA, S.R. \& Mвомe, L.I. (2008): Response surface methodology for optimisation of protein concentrate preparation from cowpea (Vigna unguiculata (L.) Walp). Fd Chem., 110, 735-741.

Mune Mune, M.A., MinkA, S.R. \& Mвоme, L.I. (2011): Functional properties of acetylated and succinylated cowpea protein concentrate and effect of enzymatic hydrolysis on solubility. Int. J. Fd Sci. Nutr., 62, 310-317.

Mwasaru, M.A., Muhammad, K., Bakar, J. \& CheMan, Y.B. (1999): Effects of isolation technique and conditions on the extractability, physicochemical and functional properties of pigeon pea (Cajanus cajan) and cowpea (Vigna unguiculata) protein isolates. I. Physicochemical properties. Fd Chem., 67, 435-443.

Myers, R.H. \& Montgomery, D.C. (2002): Response surface methodology: Process and product optimization using designed experiments ( $2^{\text {nd }}$ ed.). New York, Wiley, USA. 798 pages.

Pihlanto, A. (2006): Antioxidant peptides derived from milk proteins. Review. Int. Dairy J., 16, 1306-1314.

Shimada, K., Fujikawa, K., Yahara, K. \& Nakamura, T. (1992): Antioxidant properties of xanthium on the autooxidation of soybean oil in cyclodextrin emulsion. J. Agric. Fd Chem., 40, 945-948.

Sun, Q., Luo, Y., Shen, H. \& Hu, X. (2011): Effects of pH, temperature and enzyme to substrate ratio on the antioxidant activity of porcine hemoglobin hydrolysate prepared with pepsin. J. Fd Biochem., 35, 44-61 